\title{
RISK OF MALIGNANCY INDEX 2 IN PREOPERATIVE EVALUATION OF OVARIAN MASSES AND ITS CORRELATION WITH HISTOPATHOLOGY
}

\author{
Sarika Thakare1, Anuja Dube², Sachin Wankhede 3 \\ ${ }_{1}^{1}$ Assistant Professor, Department of Obstetrics and Gynaecology, Indira Gandhi Government Medical College, Nagpur. \\ ${ }^{2} 3^{\text {rd }}$ Year Junior Resident, Department of Obstetrics and Gynaecology, Indira Gandhi Government Medical College, Nagpur. \\ ${ }^{3}$ Associate Professor, Department of Obstetrics and Gynaecology, Indira Gandhi Government Medical College, Nagpur.
}

\section{ABSTRACT}

\section{OBJECTIVE}

To evaluate the accuracy of risk malignancy index 2 in discriminating between benign and malignant ovarian masses preoperatively in gynaecologic practice and its correlation with histopathological report.

\section{METHODS}

This was a prospective study conducted in a tertiary care hospital from consecutive 90 women with ovarian masses scheduled for surgery at Gynaecology Department between November 2013 and October 2015. After thorough history and clinical examination of patients, preoperative ultrasound findings, serum CA-125 levels and menopausal status were noted and RMI2 was calculated.

\section{RESULTS}

Incidence of benign neoplasm was $94.45 \%$, while that of malignant neoplasm was $5.55 \%$. When three parameters were separately compared with RMI2; RMI2 outperformed the others. After application of chi square test $\left(\mathrm{x}^{2}\right)$, ' $\mathrm{p}$ ' value was found to be highly significant for RMI2, USG score and CA-125.

\section{CONCLUSION}

RMI2 is more accurate in discrimination between malignant and benign ovarian masses than CA-125, USG and Menstrual score alone. It can be introduced easily into clinical practice to facilitate the selection of patients appropriate for primary surgery.

\section{KEYWORDS}

RMI2, Ovarian masses, USG score and CA-125.

HOW TO CITE THIS ARTICLE: Thakare S, Dube A, Wankhede S. Risk of malignancy index 2 in preoperative evaluation of ovarian masses and its correlation with histopathology. J. Evolution Med. Dent. Sci. 2016;5(9):376-380, DOI: 10.14260/jemds/2016/86

\section{INTRODUCTION}

Ovarian cancer is the second most common gynaecological malignancy, the fifth most common cause of death due to cancer and has more mortality than other gynaecologic malignancies.(1,2) The high mortality rate is due to difficulties with the early detection of ovarian cancer. In most cases ovarian tumour is diagnosed at an advanced stage as insidious onset and rapid progression of the tumour makes early diagnosis difficult. Early detection of ovarian malignancy is of great clinical importance.(3) The purpose of this study is to mainly detect accurately malignant ovarian tumours as early as possible by using RMI2.

\section{METHODS}

This was a prospective study conducted in a tertiary care hospital from consecutive 90 women with ovarian masses scheduled for surgery at Gynaecology Department between November 2013 and October 2015.

Women with ovarian mass of any age group diagnosed clinically or sonologically were included in the study. Whilst women with coexisting conditions like endometriosis, fibroid,

Financial or Other, Competing Interest: None.

Submission 18-12-2015, Peer Review 14-01-2016,

Acceptance 20-01-2016, Published 29-01-2016.

Corresponding Author:

Dr. Anuja Dube,

Room No. 55, NRH Hostel,

Indira Gandhi Govt. Medical College, Nagpur

E-mail: anuja.dube2@gmail.com

DOI: $10.14260 /$ jemds $/ 2016 / 86$ pregnancy, PID and with concurrent malignancy or who received neoadjuvant chemotherapy were excluded.

After thorough history and clinical examination of patients, preoperative ultrasound findings, serum CA-125 levels and menopausal status were noted.

RMI2 score.(4) was calculated as,

RMI2 score $=$ Ultrasound score $(\mathrm{U}) \times$ Menopausal score (M) x CA-125.

Women were subjected to surgery and tissue excised was sent for histopathology. Histopathological diagnosis was considered as gold standard for defining outcome and ovarian masses were classified as benign or malignant. The sensitivity and specificity of RMI2 was calculated and compared with that of individual parameters of RMI2. RMI2, USG score and CA-125 were correlated with histopathological report using chi square test $\left(\mathrm{x}^{2}\right)$ by calculating ' $\mathrm{p}$ ' value.

\begin{tabular}{|c|c|}
\hline Parameter & RMI2 \\
\hline $\begin{array}{c}\text { Ultrasound features } \\
\text { Multilocular cyst } \\
\text { Bilaterality of lesion } \\
\text { Ascites } \\
\text { Solid areas }\end{array}$ & $\begin{array}{c}1=\text { no or } 1 \text { abnormality } \\
4=>1 \text { abnormalities }\end{array}$ \\
Intra-abdominal metastasis & \\
\hline & \\
\hline Menopausal status & 1 \\
Premenopausal & 4 \\
Postmenopausal & $\mathrm{U} / \mathrm{ml}$ \\
\hline CA-125 & \\
\hline
\end{tabular}


RESULTS

1. Distribution of study subjects according to age

\begin{tabular}{|c|c|}
\hline Age (Years) & Number (\%) (n=90) \\
\hline$<30$ & $45(50.00 \%)$ \\
\hline $30-45$ & $23(25.56 \%)$ \\
\hline $45-60$ & $14(15.56 \%)$ \\
\hline$>60$ & $8(8.89 \%)$ \\
\hline
\end{tabular}

Age group less than 30 years constituted the highest number of patients, while the least incidence was seen in more than 60 years age group.

2. Distribution of study subjects according to type of ovarian mass

\begin{tabular}{|c|c|c|}
\hline HPR & $\begin{array}{c}\text { Number } \\
\text { (n=90) }\end{array}$ & Percentage \\
\hline Benign & & \\
\hline Serous Cystadenoma & 10 & $11.11 \%$ \\
\hline Mucinous Cystadenoma & 8 & $8.89 \%$ \\
\hline Dermoid Cyst & 13 & $14.45 \%$ \\
\hline Haemorrhagic Cyst & 20 & $22.22 \%$ \\
\hline Simple Cyst & 34 & $37.78 \%$ \\
\hline Total & $\mathbf{8 5}$ & $\mathbf{9 4 . 4 5 \%}$ \\
\hline Malignant & & \\
\hline Serous Cystadenocarcinoma & 3 & $3.33 \%$ \\
\hline Mucinous Cystadenocarcinoma & 1 & $1.11 \%$ \\
\hline Choriocarcinoma & 1 & $1.11 \%$ \\
\hline Total & $\mathbf{5}$ & $\mathbf{5 . 5 5 \%}$ \\
\hline
\end{tabular}

Simple cyst was most common among benign ovarian masses, while serous cystadenocarcinoma was most common among malignant cases.
3. Distribution of study subjects according to clinical symptoms

\begin{tabular}{|c|c|c|c|}
\hline Symptoms & Number & Benign & Malignant \\
\hline $\begin{array}{c}\text { Pain in } \\
\text { abdomen }\end{array}$ & $81(90 \%)$ & $79(92.94 \%)$ & $2(40 \%)$ \\
\hline $\begin{array}{c}\text { Mass in } \\
\text { abdomen }\end{array}$ & $15(16.67 \%)$ & $11(12.94 \%)$ & $4(80 \%)$ \\
\hline $\begin{array}{c}\text { Abdominal } \\
\text { distension }\end{array}$ & $10(11.11 \%)$ & $6(7.05 \%)$ & $4(80 \%)$ \\
\hline Loss of weight & $6(6.67 \%)$ & $1(1.17 \%)$ & $5(100 \%)$ \\
\hline $\begin{array}{c}\text { Loss of } \\
\text { appetite }\end{array}$ & $6(6.67 \%)$ & $1(1.17 \%)$ & $5(100 \%)$ \\
\hline
\end{tabular}

Pain in abdomen was most common mode of presentation. Loss of weight and appetite were mainly associated with malignancy.

\section{Distribution of study subjects according to menstrual} history

\begin{tabular}{|c|c|c|c|}
\hline & Benign & Malignant & Total \\
\hline $\begin{array}{c}\text { Pre- } \\
\text { menopausal }\end{array}$ & $68(80.0 \%)$ & $2(40.0 \%)$ & $70(77.77 \%)$ \\
\hline $\begin{array}{c}\text { Post- } \\
\text { menopausal }\end{array}$ & $17(20.0 \%)$ & $3(60.0 \%)$ & $20(22.23 \%)$ \\
\hline
\end{tabular}

Incidence of malignant ovarian masses was more in postmenopausal age group.

5. Distribution of study subjects according to the Ultrasound score

\begin{tabular}{|c|c|c|c|c|c|c|c|c|}
\hline \multirow{2}{*}{ HPR } & \multirow{2}{*}{ Number } & \multicolumn{5}{|c|}{ USG Findings } & \multicolumn{2}{|c|}{ Ultrasound Score } \\
\hline & & Bilateral & Loculations & Solid & Ascites & Metastasis & 1 & 4 \\
\hline \multicolumn{9}{|c|}{ Benign } \\
\hline $\begin{array}{c}\text { Serous } \\
\text { Cystadenoma }\end{array}$ & 10 & 2 & 8 & 3 & 0 & 0 & $\begin{array}{c}7 \\
(77.77 \%) \\
\end{array}$ & $\begin{array}{c}3 \\
(33.33 \%) \\
\end{array}$ \\
\hline $\begin{array}{c}\text { Mucinous } \\
\text { Cystadenoma }\end{array}$ & 8 & 0 & 8 & 3 & 1 & 0 & $\begin{array}{c}6 \\
(75 \%) \\
\end{array}$ & $\begin{array}{c}2 \\
(25 \%) \\
\end{array}$ \\
\hline Dermoid Cyst & 13 & 2 & 4 & 13 & 0 & 0 & $\begin{array}{c}8 \\
(61.53 \%) \\
\end{array}$ & $\begin{array}{c}5 \\
(38.46 \%) \\
\end{array}$ \\
\hline $\begin{array}{l}\text { Haemorrhagi } \\
\text { c Cyst }\end{array}$ & 20 & 0 & 3 & 0 & 0 & 0 & $\begin{array}{c}20 \\
(100 \%) \\
\end{array}$ & $\begin{array}{c}0 \\
(0 \%) \\
\end{array}$ \\
\hline Simple Cyst & 34 & 2 & 12 & 0 & 0 & 0 & $\begin{array}{c}32 \\
(94.11 \%) \\
\end{array}$ & $\begin{array}{c}2 \\
(5.88 \%) \\
\end{array}$ \\
\hline Total & 85 & & & & & & $\begin{array}{c}73 \\
(85.88 \%)\end{array}$ & $\begin{array}{c}12 \\
(14.11 \%)\end{array}$ \\
\hline \multicolumn{9}{|c|}{ Malignant } \\
\hline $\begin{array}{c}\text { Serous } \\
\text { Cystadenocar } \\
\text { cinoma }\end{array}$ & 3 & 1 & 1 & 3 & 3 & 1 & 0 & $\begin{array}{c}3 \\
(100 \%)\end{array}$ \\
\hline $\begin{array}{c}\text { Mucinous } \\
\text { Cystadenocar } \\
\text { cinoma } \\
\end{array}$ & 1 & 0 & 1 & 1 & 1 & 1 & 0 & $\begin{array}{c}1 \\
(100 \%)\end{array}$ \\
\hline $\begin{array}{c}\text { Choriocarcin } \\
\text { oma }\end{array}$ & 1 & 0 & 1 & 0 & 0 & 0 & $\begin{array}{c}1 \\
(100 \%) \\
\end{array}$ & 0 \\
\hline Total & 5 & & & & & & $\begin{array}{c}1 \\
(20 \%) \\
\end{array}$ & $\begin{array}{c}4 \\
(80 \%)\end{array}$ \\
\hline
\end{tabular}

Absence of all components of ultrasound score were associated with benign ovarian masses, while presence of maximum components with malignancy. Metastasis was only associated with malignancy. 
6. Distribution of study subjects according to the CA-125 levels

\begin{tabular}{|c|c|c|c|}
\hline \multirow[b]{2}{*}{ HPR } & \multirow[b]{2}{*}{ Number } & \multicolumn{2}{|c|}{ CA-125 } \\
\hline & & $\begin{array}{c}<35 \\
\text { units } / \mathrm{ml}\end{array}$ & $\begin{array}{c}>35 \\
\text { units } \\
/ \mathrm{ml}\end{array}$ \\
\hline \multicolumn{4}{|c|}{ Benign } \\
\hline Serous Cystadenoma & 10 & 8 & 2 \\
\hline $\begin{array}{c}\text { Mucinous } \\
\text { Cystadenoma }\end{array}$ & 8 & 8 & 0 \\
\hline Dermoid Cyst & 13 & 13 & 0 \\
\hline Haemorrhagic Cyst & 20 & 18 & 2 \\
\hline Simple Cyst & 34 & 33 & 1 \\
\hline Total & 85 & $\begin{array}{c}80 \\
(94.11 \%)\end{array}$ & $\begin{array}{c}5 \\
(5.88 \%) \\
\end{array}$ \\
\hline \multicolumn{4}{|c|}{ Malignant } \\
\hline $\begin{array}{c}\text { Serous } \\
\text { Cystadenocarcinoma }\end{array}$ & 3 & 0 & 3 \\
\hline $\begin{array}{c}\text { Mucinous } \\
\text { Cystadenocarcinoma }\end{array}$ & 1 & 0 & 1 \\
\hline Choriocarcinoma & 1 & 1 & 0 \\
\hline Total & 5 & $\begin{array}{c}1 \\
(20 \%)\end{array}$ & $\begin{array}{c}4 \\
(80 \%)\end{array}$ \\
\hline
\end{tabular}

CA-125 more than 35 units/ml was mostly associated with malignant cases in actual percentage terms.
7. Distribution of study subjects according to the Risk malignancy index 2

\begin{tabular}{|c|c|c|c|}
\hline \multirow{2}{*}{ HPR } & \multirow{2}{*}{ Number } & \multicolumn{2}{|c|}{ RMI-2 } \\
\hline & & $<200$ & $>200$ \\
\hline \multicolumn{4}{|c|}{ Benign } \\
\hline $\begin{array}{c}\text { Serous } \\
\text { Cystadenoma }\end{array}$ & 10 & 9 & 1 \\
\hline $\begin{array}{c}\text { Mucinous } \\
\text { Cystadenoma }\end{array}$ & 8 & 8 & 0 \\
\hline Dermoid Cyst & 13 & 12 & 1 \\
\hline Hemorrhagic Cyst & 20 & 20 & 0 \\
\hline Simple Cyst & 34 & 33 & 1 \\
\hline Total & 85 & $\begin{array}{c}82 \\
(96.47 \%)\end{array}$ & $\begin{array}{c}3 \\
(3.52 \%) \\
\end{array}$ \\
\hline \multicolumn{4}{|c|}{ Malignant } \\
\hline $\begin{array}{c}\text { Serous } \\
\text { Cystadenocarcinoma }\end{array}$ & 3 & 0 & 3 \\
\hline $\begin{array}{l}\text { Mucinous Cystadeno- } \\
\text { carcinoma }\end{array}$ & 1 & 0 & 1 \\
\hline $\begin{array}{c}\text { Chorio- } \\
\text { carcinoma }\end{array}$ & 1 & 0 & 1 \\
\hline Total & 5 & $\mathbf{0}$ & $\begin{array}{c}5 \\
(100 \%)\end{array}$ \\
\hline
\end{tabular}

RMI2 with cut off more than 200 predicted correctly all the cases of malignant ovarian masses.

8. Comparison of study subjects according to RMI2, CA-125 and Ultrasound score with Histopathological report

\begin{tabular}{|c|c|c|c|c|c|c|c|}
\hline \multirow{2}{*}{ Parameter } & \multirow{2}{*}{ HPR } & \multicolumn{2}{|c|}{ RMI2 } & \multicolumn{2}{c|}{ USG Score } & \multicolumn{2}{c|}{ CA-125 } \\
\cline { 3 - 8 } & & $\mathbf{2 0 0}$ & $\mathbf{2 0 0}$ & $\mathbf{4}$ & $\mathbf{1}$ & \multicolumn{3}{c|}{$\mathbf{3 5 u} / \mathbf{m l}$} & $<\mathbf{3 5 u} / \mathbf{m l}$ \\
\hline Malignant & 5 & 5 & 0 & 4 & 1 & 4 & 1 \\
\hline Benign & 85 & 3 & 82 & 12 & 73 & 5 & 80 \\
\hline P value & & \multicolumn{2}{|c|}{$<0.01, \mathrm{HS}$} & \multicolumn{2}{c|}{$<0.01, \mathrm{HS}$} & \multicolumn{2}{c|}{$<0.01, \mathrm{HS}$} \\
\hline
\end{tabular}

False positive cases were more with ultrasound score and CA-125 score when used alone. RMI2 predicted cent percent malignant cases accurately. After application of chi square test $\left(\mathrm{x}^{2}\right)$ ' $\mathrm{p}$ ' value was found to be highly significant for RMI2, USG score and CA-125.

9. Comparison of RMI2, CA-125, Ultrasound score and Menopausal score according to sensitivity and specificity values

\begin{tabular}{|c|c|c|}
\hline PARAMETER & SENSITIVITY & SPECIFICITY \\
\hline RMI2 & $100.0 \%$ & $96.47 \%$ \\
\hline CA-125 & $80.0 \%$ & $94.0 \%$ \\
\hline ULTRASOUND SCORE & $80.0 \%$ & $85.8 \%$ \\
\hline MENOPAUSAL SCORE & $60.0 \%$ & $80.0 \%$ \\
\hline
\end{tabular}

RMI-2 outperformed CA-125, Ultrasound score and Menopausal score in terms of sensitivity and specificity.

\section{DISCUSSION}

The prevalence of malignant ovarian masses has been rising in last 30-40 years. Since its occurrence and development is very latent and since there have been very few effective tools for early diagnosis and treatment, its mortality rate has been highest among gynaecological malignancies. So a new method of early diagnosis would have a great significance for prediction of prognosis and treatment of malignant ovarian masses. (5) At the same time detection of benign ovarian masses accurately will prevent unnecessary laparotomies.

Serum CA-125 was earlier used as an independent marker for preoperative evaluation.(6) The limiting factor of CA-125 is that it may be raised in benign diseases like haemorrhagic ovarian cyst, inflammatory conditions, PID and endometriosis. The combination of CA-125, ultrasound score and menopausal status increases the discriminating power of the method.

The Risk Malignancy Index (RMI) is useful in clinical practice for differentiating malignant from benign ovarian masses as compared to each individual component measured separately.(7) In the present study, we have used RMI2 developed by Tingulstads et al. in 1996.(4)

\section{AGE}

In the present study maximum cases were found in age group below 30 years, i.e. $50.0 \%$, while least cases were found in age group more than 60 years, i.e. $8.89 \%$. With increasing age, rate of malignancy increases. In the present study, 4 malignant ovarian masses $(80.0 \%)$ were in the age group above 45 years, while only 1 case (20\%) was in age group less than 30 years. Our findings were similar to studies conducted by Jung Woo Park et al.(8) and Veluswamy Arun Muthuvel et al.(9), wherein age group less than 45 years constituted the largest group and rate of malignant ovarian masses were highest in age group above 45 years. In the present study, youngest patient was 12 years old and oldest patient was 70 years old.

\section{Menstrual History}

In our study, we observed that $77.77 \%$ and $22.23 \%$ patients were premenopausal and postmenopausal respectively. Malignant tumours were common in postmenopausal women. Similarly in studies conducted by MA Shuiqing et al.(10), Jung Woo Park et al.(8) and Zinatossada Bouzari et al.(11) observed overall incidence of ovarian masses was less in postmenopausal patients. Earlier menstrual score alone was used 
in predicting malignancy. In the present study, we found that menstrual score alone if used for predicting malignancy had a sensitivity of $60.0 \%$ and specificity of $80.0 \%$. Our results were similar to Jose Carlos Campose et al.(7) and Veluswamy Arun Muthuvel et al.(9) Hence, menstrual score alone is not a good predictor of malignancy. If it has been used for the same then the rate of unnecessary laparotomies or major surgeries will increase while many malignant cases which occur in premenopausal age group will be missed.

\section{Symptoms}

In the present study, we observed that most common mode of presentation was pain in abdomen and was seen in $90 \%$ of patients. Also it was the most common mode of presentation in benign masses. Loss of weight and appetite were present in $6.67 \%$ patients which were mainly associated with malignancy. Our study results were similar to Farah Farzaneh et al.(12) who also observed weight loss to be mainly associated with malignancy.

\section{Incidence of different types of Ovarian Masses}

In the present study incidence of benign neoplasm was $94.45 \%$, while that of malignant neoplasm was $5.55 \%$. In benign masses, simple cyst constituted the largest group (40.0\%) followed by haemorrhagic cyst (23.52\%). In malignant ovarian masses, serous cystadenocarcinoma was the most common $(60.0 \%)$ followed by 1 case of mucinous cystadenocarcinoma and choriocarcinoma each. Our study had fewer incidence of malignant ovarian tumours. It may be because clinical data was obtained from a single institute, as was the case with the study conducted by R. C. Prameela et al.(13) who also noted an incidence of ovarian malignancy to be less and the data was collected from a single institute just like ours.

\section{Ultrasound Score}

The recent advance development of ultrasound techniques and the better characterization of malignant tumours by this method have lead to better performance of ultrasound as a predictor of malignancy, especially in those cases with metastasis.(14)

In the present study we observed that ultrasonography diagnosed correctly 4 cases (80\%) of malignant ovarian masses, but it falsely diagnosed 12 cases $(14.11 \%)$ of benign masses as malignant; mainly of dermoid cyst and cystadenomas. It can be explained by the fact that multilocular cyst may be found in cystadenoma and solid parts found in dermoid cyst.(15) Ascites and metastasis were associated with malignant cases only. The sensitivity and specificity of USG score for diagnosing malignant ovarian masses was $80.0 \%$ and $85.8 \%$ respectively, which was similar to studies conducted by MA Shuiqing et al.(10) and Jung Woo Park et al.(8), wherein the sensitivity was $94.7 \%$ and $93.7 \%$ and specificity was $83.1 \%$ and $86.3 \%$ respectively.

The absence of all components of ultrasound score were associated with benign ovarian masses, while presence of maximum features with malignancy.(9) Ultrasonography morphological score should be developed further to improve the detection rate of malignancy.

\section{CA-125}

In the present study, CA-125 was accurate in predicting malignancy in $80.0 \%$ of cases. However, there were false elevations in 2 cases of haemorrhagic cyst (2.33\%), 2 cases of serous cystadenoma (2.33\%) and 1 case of simple cyst $(1.17 \%)$. It was falsely negative in 1 case of mucinous cystadenocarcinoma, i.e. $20 \%$. This can be explained by the fact that mucinous tumours expressed CA-125 less frequently than non-mucinous tumours.(16) Also CA-125 is a tumour marker with highest specificity for epithelial ovarian masses.(17) In premenopausal patients, CA-125 was not accurate enough to predict malignancies and was falsely elevated in cases with haemorrhagic cyst, endometriosis and pelvic infections. ${ }^{(18-20)}$

The sensitivity and specificity of CA-125 in predicting malignancy in the present study was $80.0 \%$ and $94.12 \%$ respectively, which was slightly better than studies conducted by Jose Carlos Compose et al.(7) and Erhan Akturk et al.(21) with sensitivity of $78.0 \%$ and $75.0 \%$, while specificity of $75.0 \%$ and $75.0 \%$ respectively.

\section{RMI}

In the present study, we used RMI2 developed by Tingulstads et al. with cut off of 200 . It predicted all malignant masses accurately giving a cent percent sensitivity and specificity in malignant cases. It was falsely elevated in 1 case of dermoid cyst $(1.17 \%), 1$ case of simple cyst $(1.17 \%)$ and 1 case of serous cystadenoma (1.17\%), which may be due to high ultrasound score and high CA- 125 levels. Its overall sensitivity is $100.0 \%$ and specificity is $96.47 \%$. Our study results were comparable and slightly better than conducted by Veluswamy Arun Muthuvel et al.(9) Jung Woo Park et al.(8) MA Shuiqing et al.(10) and Erhan Akturk et al.(21) Difference could be due to different study population and difference in incidence of malignant ovarian masses.

\section{Comparison of RMI2 with individual parameters (Ultrasound Score, Menopausal Score and CA-125 level)}

When three parameters were separately compared with RMI2; RMI2 outperformed the others. Menopausal score was nowhere near the performance of RMI2. While ultrasound score and CA-125 had better performance than menopausal score. RMI2 had highest sensitivity and specificity. False positive cases were highest with menopausal score followed by ultrasound score. False negative cases were more with menopausal score followed by CA-125 and ultrasound score. Application of ultrasound and CA-125 individually would have resulted in lots of unnecessary laparotomies or major surgeries. After application of chi square test $\left(x^{2}\right)$, ' $p$ ' value was found to be highly significant for RMI2, USG score and CA-125.

Recently laparoscopic surgeries are being performed widely for treatment of ovarian tumours.(22) The safety of laparoscopic surgery for ovarian masses is still unclear because of possible complications such as intraoperative cyst rupture, spillage of cyst contents, chemical peritonitis and unexpected malignant tumours. Hence, preoperative diagnosis to estimate RMI in patient with ovarian masses who are admitted for laparoscopic surgery can enable surgeon to be optimally prepared before surgery.

\section{CONCLUSION}

Incidence of malignant ovarian masses in our institute was $5.55 \%$. Our study demonstrated that RMI2 is more accurate in discrimination between malignant and benign ovarian masses than CA-125, USG and Menstrual score alone. It can be 
introduced easily into clinical practice to facilitate the selection of patients appropriate for primary surgery.

Since the specificity of RMI2 is high; there is potential role for this index in the selection of cases for conservative management or minimal invasive surgery for benign masses like Ultrasound guided aspiration or laparoscopic excision of benign cyst.

\section{REFERENCES}

1. Greenlee R, Hill Harom M, Murray T, et al. Cancer statistics, 2001. CA; A cancer journal for clinicians 2001;51(1):15-36.

2. Landis S, Murray T, Bolden S, et al. Cancer statistics. Cancer J Clin 1998;48:6-29.

3. Garcia M, Jenal A and Ward EM. Global cancer facts and figures 2007. Atlanta, GA. American cancer society 2007;4-5.

4. Tingulstad S, Hagen B, Skjeldestad FE, et al. Evaluation of a risk of malignancy index based on serum levels of CA125 , ultrasound findings and menopausal status in the preoperative diagnosis of pelvic masses. $\mathrm{Br} \mathrm{J}$ Obstet Gynaecol 1996;103:826-31.

5. Guidozzi F. Screening for ovarian cancer. Obset Gynecol Surv 1996;51:696-701.

6. Antovska S, Bashevska N and Aleksioska N: Predictive values of the ultrasound parameters, CA-125 and risk of malignancy index in patients with ovarian cancer. Klin Onkol, 2011;24(6):435-442.

7. Jose T, Sophie D, Anival F, et al. Risk of malignancy index in preoperative evaluation of clinically restricted ovarian cancer. Sao Paulo Med J/Rev Paul Med 2002;120(3):7276.

8. Jung-Woo P, Jee-Hyun P, Song ES, et al. Four risk of malignancy indices in evaluation of pelvic masses. Korean J Obstet Gynecol 2012;55(9):636-643.

9. Muthuvel VA and Jaya V. Preoperative evaluation of ovarian tumors by risk of malignancy index, CA-125 and Ultrasound. Asian Pac J Cancer Prev 2014;15(6):29292932.

10. Shuiqing MA, Keng S and Jinghe L. A risk of malignancy index in preoperative diagnosis of ovarian cancer. Chinese Medical Journal 2003;116(3):396-399.

11. Bouzari Z, Yazdani S, Ahmadi MH, et al. Comparison of three malignancy risk indices and CA-125 in the preoperative evaluation of patients with pelvic masses. BMC Research Notes 2011;4:206.
12. Farzaneh F, Honarvar Z, Yaraghi M, et al. Preoperative evaluation of ovarian malignancy algorithm index in prediction of malignancy of adnexal masses. Iran Red Crescent Med Journal, 5 June 2014; 20, 4.

13. Prameela RC, Lokhapur G and Ranganath P. Role of risk malignancy index in predicting ovarian malignancy and its correlation with Histopathological report. Sch. J. App. Med. Sci. 2014;3(1G):490-493.

14. Kurjak A, Zalud I and Alfirevic Z. Evaluation of adnexal masses with transvaginal colour ultrasound. J Ultrasound Med 1991;10:295-7.

15. Putsarat I and Nisa P. Evaluation of four risk of malignancy indices in the preoperative diagnosis of ovarian malignancy at Rajavithi Hospital. Thai Journal of Obstetrics and Gynaecology, Oct 2013, vol 21, 163-175.

16. Gadducci A, Ferdeghini M, Prontera C, et al. The concomitant determination of different tumor markers in patients with epithelial ovarian cancer and benign ovarian masses: relevance for differential diagnosis. Gynaecol Oncol 1992;44:147-54.

17. Jing B, Bo Li, Kou XJ, et al. Clinical significance of combined detection of serum tumor markers in diagnosis of patients with ovarian cancer. Asian Pac J Cancer Prev. 14(11), 6241-6243.

18. Maggino T, Gadducci A, D'Addario V, et al. Prospective multicenter study on CA-125 in postmenopausal pelvic masses. Gynaecol Oncol 1994;54:117-123.

19. Schutter EM, Kenemans P, Sohn C, et al. Diagnostic value of pelvic examination, ultrasound and serum CA-125 in postmenopausal women with a pelvic mass. An International multicenter study.

Cancer 1994;74:1398-406.

20. Berek JS and Bast RC. Ovarian cancer screening. The use of serial complementary tumor markers to improve sensitivity and specificity for early detection. Cancer 1995;76(10 suppl):2092-2096.

21. Akturk E, Karaca RE, Alanbay I, et al. Comparison of four malignancy risk indices in the detection of malignant ovarian masses. J Gynecol Oncol, vol 22, No 3; 177-182.

22. Mecke H and Savvas V. Laparoscopic surgery of dermoid cysts: intraoperative spillage and complications. Eur J Obstet Gynaecol Reprod Biol 2001;96:80-84. 